\title{
Breeding Birds of Arctic Bay, Baffin Island, N.W.T., with Notes on the Biogeographic Significance of the Avifauna
}

\author{
WAYNE E. RENAUD ${ }^{1}$, STEPHEN R. JOHNSON ${ }^{2}$ and P. DIANE \\ HOLLINGDALE
}

\begin{abstract}
The known avifauna of the Arctic Bay area consists of 38 species, of which 22 are probable or proven breeders and 3 are permanent residents. Arctic Bay appears to be in a transition area between characteristic high arctic and low arctic forms. Eurasian or Greenlandic forms include breeding Ringed Plover and 'Greenland' Hoary Redpoll; and transient Wheatear, Red Knot and Ruddy Turnstone. The absence of several sea-associated species as breeders or even transients may be attributed to the normal late ice break-up in Admiralty Inlet.
\end{abstract}

\begin{abstract}
RESUME. La faune d'oiseaux de la baie arctique est riche de 38 espèces dont 22 sont des reproducteurs probables au prouvés et 3 sont des résidents permanents.

La baie arctique parait être une region de transition entre les formes caracteristiques du "haut et du bas arctique." Les formes Eurasiennes ou Groenlandaises incluent les races des pluviers annelés; les têtes rouges à plumes blanches du groenland; aussi les "culs blancs", les noeuds rouges et les pluviers rougeâtres de passage; on peut attribuer à la fonte tardive normale des glaces dans le baie de l'Amirauté, l'absence de quelques espéces d'oiseaux de mer, tant pour les reproducteurs que pour les passagers.

Traduit par Alain de Vendegies, Aquitaine Company of Canada Ltd.
\end{abstract}

While conducting a study of bird distribution in eastern Lancaster Sound, the writers were present at Arctic Bay, Baffin Island, N.W.T. $\left(7^{\circ} 02^{\prime}\right.$ N., $84^{\circ} 11^{\prime} \mathrm{W}$.), from 1 May to 28 September 1976 . During this period most of the authors' observations were made within $10 \mathrm{~km}$ of Arctic Bay.

\section{DESCRIPTION OF AREA}

Figure 1 shows Arctic Bay and surrounding area. In contrast to the high plateau and steep cliffs that border most of northern Admiralty Inlet, the topography in the vicinity of Arctic Bay is low and rolling. The highest elevations occur on the Uluksan Peninsula $(456 \mathrm{~m})$ and at King George $\mathrm{V}$ Mountain $(549 \mathrm{~m})$. In many places the land rises gradually from the coast to the upper plateau. Near Marcil Lake and east of Victor Bay the lowlands support occasional tundra ponds. In other areas, especially along St. George's Society Cliffs, precipitous cliffs up to $225 \mathrm{~m}$ high rise from the fiords.

\footnotetext{
' LGL Ltd. - environmental research associates, 44 Eglinton Ave. W., Toronto, Ontario. M4R 1A1.

${ }^{2}$ LGL Ltd. - environmental research associates, 10110 - 124 St., Edmonton, Alberta. T5N 1P6.
} 
The uplands of the Uluksan Peninsula and much of the area between Adams Sound and Strathcona Sound are rocky and barren with little vegetation and few lakes and ponds. The vegetation communities in the immediate vicinity of Arctic Bay are relatively lush and in lowland areas (e.g. northwest of Marcil Lake) completely cover the ground. A more detailed description of topography and vegetation is given by Polunin (1948).

\section{WEATHER IN 1976}

In 1976, the temperature first rose to $0^{\circ} \mathrm{C}$ on 19 May, then remained below freezing until 29 May. Daily maximum temperatures at or above freezing were recorded on every day thereafter until 16 September. The coldest temperature between 1 May and 28 September was $-24^{\circ} \mathrm{C}$ on 8 and 12 May; the maximum temperature was $15^{\circ} \mathrm{C}$ on 27 July. Mean monthly temperatures were $4^{\circ} \mathrm{C}$ below normal in May, and within $1^{\circ} \mathrm{C}$ of normal from June to September.

Some south-facing slopes became bare of snow in late May before the maximum daily temperatures rose above freezing. Snow cover was estimated

FIG. 1. Map of Arctic Bay area.

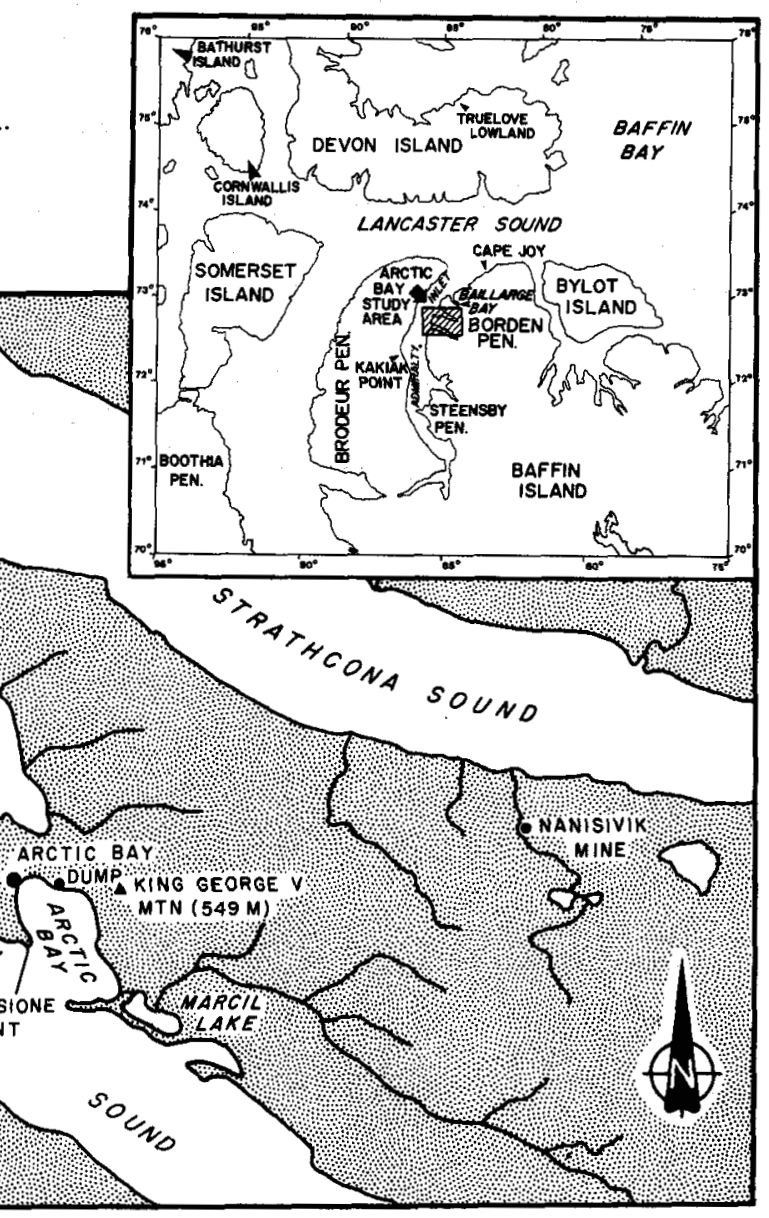


to be $50 \%$ on 15 June and $20 \%$ on 30 June. Frequent snow and rain storms occurred throughout June and early July. New snow had covered all areas above $450 \mathrm{~m}$ by late August; this snow did not melt during September.

Tundra ponds became ice-free during the second week of June. The sea-ice broke during the last week of July and the first week of August. Little sea-ice remained in the area by 1 September. Ponds contained varying amounts of ice by the second week of September, but did not completely freeze until the third week. Marcil Lake, the largest body of fresh water in the area, did not become ice-free until late August; it was still $95 \%$ ice-free when we left the area on 28 September. The first permanent snowfall at sea level occurred on 26 September.

\section{THE AVIFAUNA OF THE ARCTIC BAY AREA}

All bird records for the Arctic Bay area are summarized in Table 1. Previous visits by ornithologists to the Arctic Bay area have been either brief or limited to the late fall, winter or early spring. The nearest comprehensive avifaunal surveys are from Bylot Island (Van Tyne and Drury, 1959; Tuck and Lemieux, 1959; Drury, 1960, 1961a,b,c), Truelove Lowland, Devon Island (Hussell and Holroyd, 1974; Pattie, 1977), Resolute, Cornwallis Island (Geale, 1971) and the Melville Peninsula (Bray, 1943).

We observed a total of 31 species of birds in the Arctic Bay area in 1976. Our records of eggs or dependent young are the first proof of breeding by 17 species at Arctic Bay. Three other species may have nested in or near the area in 1976, and previous observers have breeding records for 2 additional

TABLE 1. List of species reported by various sources in the Arctic Bay area. (' - ' = not recorded; ' + ' = recorded but no direct evidence of breeding; ' $B$ ' = direct evidence of breeding.)

\begin{tabular}{|c|c|c|c|c|c|}
\hline SPECIES & 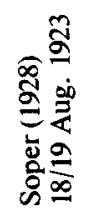 & 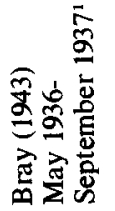 & 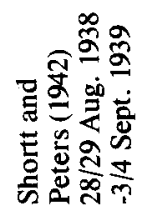 & 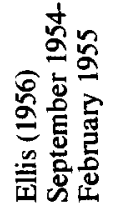 & 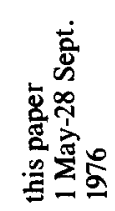 \\
\hline
\end{tabular}

Arctic Loon

Red-throated Loon

Northern Fulmar

Snow Goose

Oldsquaw

Common Eider

King Eider

Rough-legged Hawk

Gyrfalcon

$\begin{array}{lllll}- & - & + & - & - \\ - & - & - & - & \text { B } \\ + & + & + & + & + \\ + & - & - & - & \text { B } \\ - & - & - & + & \text { B } \\ - & - & + & - & + \\ - & - & - & \text { B } & + \\ - & - & - & - & \text { B } \\ + & \text { B } & - & - & +\end{array}$


TABLE 1 - Cont'd

\begin{tabular}{|c|c|c|c|c|c|}
\hline SPECIES & 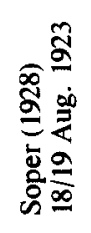 & 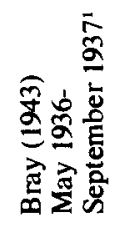 & 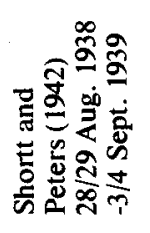 & 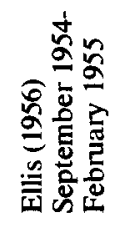 & 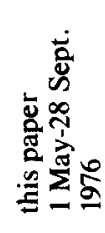 \\
\hline Peregrine Falcon & - & - & + & - & - \\
\hline Rock Ptarmigan & - & - & + & + & B \\
\hline Ringed Plover & - & + & - & - & B \\
\hline American Golden Plover & - & - & - & - & B \\
\hline Black-bellied Plover & - & - & - & - & + \\
\hline Whimbrel & - & + & - & - & - \\
\hline Ruddy Turnstone & - & - & - & - & + \\
\hline Red Knot & - & - & - & - & + \\
\hline Pectoral Sandpiper & - & - & - & - & B \\
\hline White-rumped Sandpiper & - & - & + & - & B \\
\hline Baird's Sandpiper & - & - & + & - & B \\
\hline Red Phalarope & - & - & - & - & + \\
\hline Long-tailed Jaeger & - & - & - & - & B \\
\hline Glaucous Gull & - & - & - & + & B \\
\hline Thayer's Gull & - & - & + & - & B \\
\hline Black-legged Kittiwake & + & - & - & + & - \\
\hline Ivory Gull & - & + & - & - & $\mathrm{B}$ ? \\
\hline Thick-billed Murre & + & - & - & - & - \\
\hline Dovekie & - & - & - & + & - \\
\hline Black Guillemot & - & - & - & + & + \\
\hline Snowy Owl & - & - & - & + & + \\
\hline Horned Lark & + & - & + & - & B \\
\hline Bank Swallow ${ }^{2}$ & - & - & - & - & - \\
\hline Common Raven & + & - & + & + & B \\
\hline Wheatear & - & + & + & - & + \\
\hline Water Pipit & - & - & + & + & B? \\
\hline Wilson's Warbler ${ }^{3}$ & - & - & - & - & - \\
\hline Hoary Redpoll & - & + & - & + & B? \\
\hline Lapland Longspur & - & - & + & - & B \\
\hline Snow Bunting & - & - & + & - & B \\
\hline
\end{tabular}

${ }^{1}$ Duration of stay in the Southampton - Baffin Island - Melville Peninsula area; time spent at Arctic Bay not specifically given.

${ }^{2}$ A specimen in the Royal Ontario Museum (ROM) was collected at Arctic Bay on 13 June 1951 (Snyder 1957).

${ }^{3}$ A specimen in the ROM was collected at Arctic Bay in mid-July, 1957 (Snyder 1957). 
species not found breeding in 1976. Nine species recorded in 1976 had not been previously recorded at Arctic Bay, and eight species previously recorded were not observed in 1976.

Thirteen species found nesting in the Arctic Bay area have circumpolar breeding distributions. Nine of these 13 species nest throughout the arctic (trans-arctic); two nest mostly in the northern portions of the arctic (high arctic); and two nest mostly in the southern portions of the arctic (low arctic). Six species nesting in the area have primarily North American breeding ranges. One of these New World arctic species has a trans-arctic distribution, three nest mostly in the high arctic and two nest mostly in the low arctic. Only one of the species is considered to have a predominantly Eurasian breeding distribution, and two species have a cosmopolitan distribution.

SPECIES BREEDING IN THE ARCTIC BAY AREA

\section{Circumpolar, Trans-Arctic Species}

RED-THROATED LOON. Gavia stellata. First individuals noted on 18 June and 22 June. On 3 July, two pairs were near nests (each with two eggs) along the river below Marcil Lake; by 24 July both nests had been inundated by a 45 $\mathrm{cm}$ rise in water levels. On 1 September an adult was seen carrying food to a nearly full-grown young on a pond near Victor Bay. The young bird had left by 10 September.

OLDSQUAW. Clangula hyemalis. First noted on 18 June; a courting pair was seen on a run-off pond near Marcil Lake. The latest observation was made on 31 July. A female and seven young ( $\sim 2$ days old $)$ were observed on a small pond near the top of St. George's Society Cliffs on 28 July.

KING EIDER. Somateria spectabilis. First noted on 17 June; a flock of 12 flying along the bayshore. A male and two females were observed courting on a pond northwest of Marcil Lake on 18 June, and on 24 June a pair was seen on the river below Marcil Lake. The species was not observed again until 7 August, when a flock of 400 (all females except for five males) was seen flying back and forth over the bay. Flocks of 8 to 180 female eiders were regularly observed flying over the bay from 15 to 23 August. During September, flocks of up to 60 individuals, again all females, were oberved flying over the bay. There was no evidence that this species nested locally in 1976, but Ellis (1956) observed female and immature King Eiders at Arctic Bay during late August, September and October in 1954; a flock of 50 remained until 18 October. One immature collected on the latter date was still flightless.

GYRFALCON. Falco rusticolus. Noted definitely only twice. A white-phase individual on 22 May, and a light-phase individual (white or light grey) on 31 August. A large, dark falcon being pursued by a Long-tailed Jaeger near Marcil Lake on 24 July appeared to be this species.

Evidently none nested in the immediate vicinity of Arctic Bay, but in late May, D. Ipirq (pers. comm.) observed a nest with eggs $40 \mathrm{~km}$ southwest of Arctic Bay. 
ROCK PTARMIGAN. Lagopus mutus. Local Inuit indicated that the species is a permanent resident and that during mid-winter ptarmigan occasionally come into the village. On 7 August we observed two broods of 8 and 14 young $(\sim 3$ weeks old $)$.

LONG-TAILED JAEGER. Stercorarius longicaudus. First noted on 8 June; a pair heard calling and later seen dropping from a considerable altitude (perhaps as much as $600 \mathrm{~m}$ ) to the tundra east of Victor Bay. Long-tailed Jaegers were recorded on most hikes away from the village during June and July. At least two pairs maintained territories within $2 \mathrm{~km}$ of the village but there was no evidence that these birds nested. A nest containing one egg was found on well-drained Dryas/Carex tundra on 18 June; on 24 June there were two eggs, and on 17 August one fledged young. A second nest containing two eggs was found on lichen/Dryas tundra on 26 June; there were two eggs on 14 July. A third nest containing one egg was found in lichen/Dryas tundra on a raised beach on 14 July. The last jaegers were observed on 23 August.

HOARY REDPOLL. Carduelis hornemanni. Redpolls appeared to be resident on talus slopes throughout the area. First observed on 6 May when two individuals, one of which was seen well and had a clear, white rump, flew along the cliffs near Arctic Bay. The only other satisfactory identification of this species was on 23 July (two birds). Ellis (1956) noted redpolls at Arctic Bay throughout the winter of 1954-55, and Bray (1943) reported that they were common in the winter of 1936-37.

LAPLAND LONGSPUR. Calcarius lapponicus. First noted on 22 May. Males were already carrying nest material on 23 May, when some males were still in small groups and it appeared that migration was still in progress. The first female was seen on 2 June. Nests were found on 10 June (completed, but empty), 24 June (4 eggs, 6 eggs on 26 June), 30 June (four large young and an addled egg), and 3 July ( 3 young about two days old). By mid-July there were many fledged young with the adults, and the males were in heavy moult; the largest group observed was of 15 on 23 July. The species became much less common during the latter half of August. The latest observation was on 2 September.

SNOW BUNTING. Plectrophenax nivalis. First recorded on $3 \mathrm{May}$; two seen at the dump (Frank Pierce, settlement manager). The first large flocks were noted during a snow storm on 11 and 12 May (36 individuals). Flocks of 10 to 30 were observed on patches of bare ground throughout the area in late May (maximum, 55 on 26 May). Territorial singing was first noted on 24 May in the village. On 25 May singing males were noted at elevations up to $500 \mathrm{~m}$ on King George V Mountain. Nest-building was noted from 4 to 15 June. Nests were found on 15 June (6, 3, 0 eggs), 18 June ( 2 eggs), 26 June (6 eggs) and 14 July (3+ large young); the nest that contained three eggs on 15 June contained six young on 3 July. All nests were under or among rocks. Flocks began to gather by early September (max., 23 on 2 September). The latest observation was of two on 17 September. 


\section{Circumpolar, Low Arctic Species}

ROUGH-LEGGED HAWK. Buteo lagopus. First noted on 26 May. Rough-legged Hawks were present at two known nest sites on 27 May. One nest contained four eggs on 4 June, five eggs on 24 June, and at least two young on 14 July. The only prey items noted around the nest on 14 July were feathers of newly-fledged passerines. The second nest contained two eggs on 15 June and two young on 28 July. From one to three Rough-legged Hawks were noted regularly near Arctic Bay until 8 September, our latest record. All birds had light-phase plumage.

The breeding range of the Rough-legged Hawk in the arctic islands is poorly known (Snyder, 1957; Godfrey, 1966). These are the first definite breeding records for northern Baffin Island although it has been recorded breeding to the northeast on Bylot Island (Tuck and Lemieux, 1959).

WATER PIPIT. Anthus spinoletta. First noted on 22 May. On 24 June, one member of a pair observed in the gorge of a river draining into Marcil Lake was displaying. An adult and a fledged juvenile were seen on 23 August (K. Finley, LGL Ltd., pers. comm.). Pipits were last observed on 15 September. Ellis (1956) recorded the latest migrants on 27 September.

\section{Circumpolar, High Arctic Species}

GLAUCOUS GULL. Larus hyperboreus. First noted on the morning of 22 May when flocks of up to seven were seen flying to and from the direction of Victory Bay; by late afternoon at least 53 adults were assembled on the bay-ice near the dump. On this date, the nearest open water was at the mouth of Admiralty Inlet at least $90 \mathrm{~km}$ away. Thereafter, Glaucous Gulls were observed daily. The first immature (a 2 nd-year bird) was observed on 18 June.

A mixed colony of about 125 pairs of Thayer's and Glaucous Gulls nested on a broad ledge about $30 \mathrm{~m}$ from the top of the $225-\mathrm{m} \mathrm{St}$. George's Society Cliffs. At least 25 young gulls, the oldest of which were about three weeks old, were observed on a part of the ledge on 28 July. On 5 July a Glaucous Gull was found incubating on a sea-cliff $9 \mathrm{~km}$ east of Oulouksione Point. When the ice began to break-up in mid to late July, fewer Glaucous Gulls were noted in the immediate vicinity of Arctic Bay, but during late August and September up to 100 were frequently observed at Marcil Lake. The species was still present when we left the area on 28 September. Ellis (1956) observed Glaucous Gulls at Arctic Bay until ice formed on the bay on 18 October 1954.

IVORY GULL. Pagophila eburnea. The first Ivory Gulls, four adults, were observed on 10 June feeding on seal carcasses on the bay-ice in front of the village. Head-bobbing behaviour was exhibited by three pairs on 11 June. Thereafter, until 3 July, the species appeared daily to feed on seal carcasses discarded by Inuit hunters. Seldom were more than six Ivory Gulls noted at one time with a maximum of 11 on 21 June. The gulls had a regular feeding schedule, arriving in the bay between 2000 and $2200 \mathrm{hrs}$. and departing by $0700 \mathrm{hrs}$. By early July the seal carcasses began to sink as the sea-ice melted 
and there was less food available for the Ivory Gulls. Thereafter, only single birds were noted on 7 and 8 July, and from one to six individuals, all adults, were seen on seven dates from 15 to 27 August. None was observed during September.

David Ipirq, a local resident and well-travelled hunter, reported that he had found a colony on an ice-cap of the Brodeur Peninsula about $50 \mathrm{~km}$ northwest of Arctic Bay $\left(7^{\circ} 30^{\prime} \mathrm{N} ; 86^{\circ} 45^{\prime} \mathrm{W}\right)$. Timothy Idlout (fide K. J. Finley, LGL Ltd.) reported that he had found a colony on the Brodeur Peninsula one year during June while travelling by dog-sled between southeast Somerset Island and Arctic Bay; the site was said to have been on a high, barren, gravel plain at approximately $72^{\circ} 57^{\prime} \mathrm{N}, 8^{\circ} 30^{\prime} \mathrm{W}$. Further evidence of a colony somewhere on northwest Baffin Island is given by reports of adults, and later young, at Kakiak Point $65 \mathrm{~km}$ southwest of Arctic Bay during mid- to late August 1976 (R. Greendale and W. Doidge, Canada Fisheries and Marine Service, pers. comm.). Five previous unsubstantiated reports of Ivory Gulls breeding on the Brodeur Peninsula were reviewed by MacDonald and MacPherson (1962).

\section{North American, Trans-Arctic Species}

SNOW GOOSE. Chen caerulescens. The first spring observation was a flock of five on 5 June. On 6 June a flock of seven contained one blue-phase individual. During July, about 180 Snow Geese (including 1 blue-phase bird) moulted along an unnamed river draining into Strathcona Sound $10 \mathrm{~km}$ northeast of Nanisivik Mine. One nest was seen there on 6 July. Two adults with six young were seen at Marcil Lake on 24 July and 7 August. Snow Geese were last seen on 6 September (flocks of 30 and 16).

\section{North American, Low Arctic Species}

AMERICAN GOLDEN PLOVER. Pluvialis dominica. First noted on 6 June; two individuals (1 performing an aerial display). On 3 July a nest with four eggs was found in rocky sedge-tundra northwest of Marcil Lake. The latest observation was a single individual on 23 August (K. J. Finley).

PECTORAL SANDPIPER. Calidris melanotos. Observed on three occasions on the tundra northwest of Marcil Lake. Three (two were males performing aerial displays) were noted on wet moss/sedge tundra on 18 June. On 24 July, three adults and one young ( $\sim 5$ days old) were seen. On 7 August one was seen in the same area.

This is the first breeding record on northern Baffin Island, although the species has recently been found nesting sporadically and locally north to Truelove Lowland, Devon Island (Hussell and Holroyd, 1974), and Mecham River, Melville Island (LGL Ltd., unpubl. data).

\section{North American, High Arctic Species}

WHITE-RUMPED SANDPIPER. Calidris fuscicollis. First recorded on 18 June when at least 12 individuals were performing aerial displays over the tundra west of Marcil Lake. On 24 July an adult with one young ( $\sim 4$ days old) was seen in moss/sedge tundra near the outlet of the river draining from 
Marcil Lake. No other White-rumped Sandpipers were seen in this area although much time was spent searching for young. A large, flightless young was repeatedly observed near a dog carcass on 8-10 August; both the young and an accompanying adult were evidently attracted to the carcass by insects. The species was last observed on 2 September.

This is the first breeding record for northern Baffin Island; it has been recorded breeding throughout the mid-arctic islands north to Bylot Island (Tuck and Lemieux, 1959; Van Tyne and Drury, 1959); Truelove Lowland, Devon Island (Hussell and Holroyd, 1974); and probably northwest Cornwallis Island (LGL Ltd, unpubl. data) and Melville Island (Maltby, 1975).

BAIRD'S SANDPIPER. Calidris bairdii. This was the most abundant shorebird in the Arctic Bay area. The first arrivals (five individuals) were noted on 3 June. On that date one individual displaying west of the village repeatedly drove a pair of Snow Buntings from a patch of snow-free ground. During a 16-km hike on 4 June at least 19 Baird's Sandpipers were observed as individuals or pairs, and much territorial behaviour was noted. Territorial displaying was most intense during the first two weeks of June. Five nests (4 with 4 eggs; 1 with $1 \mathrm{egg}$ ) were found between 18 June and 3 July. Nesting habitats varied from wet Carex meadows to dry talus slopes and sparsely-vegetated alluvial flats. On 24 July, four broods (1, 2, 2, 3 young) were noted on the flats near Marcil Lake. The oldest young were capable of sustained flights, indicating that they were at least three weeks old ( $c f$. Parmelee et al., 1967). By late July most of the upland habitats had been abandoned; few were observed except along the edges of ponds and tidal pools. The latest observation was on 17 August.

THAYER'S GULL. Larus thayeri. First observed on 27 May. During June, July and August this species was observed on most days, although it was usually much less common near the village than was the Glaucous Gull. Thayer's Gulls comprised 50 to $65 \%$ of the total adults observed at the gull colony on St. George's Society Cliffs. Thayer's Gulls were still present when we left the area on 28 September.

Although no gulls in the Arctic Bay area were examined in the hand, all Larus Gulls with black-tipped wings were considered to be Thayer's in view of Smith's (1966) work on the distribution of this species.

\section{Eurasian, Trans-Arctic Species}

RINGED PLOVER. Charadrius hiaticula. All small plovers noted at Arctic Bay are treated as $C$. hiaticula. Only $C$. hiaticula has been collected or observed at Arctic Bay (Bray, 1943), on Bylot Island (Tuck and Lemieux, 1959; van Tyne and Drury, 1959), and at Pond Inlet (Soper, 1928; Shortt and Peters, 1942). However, there are records of $C$. semipalmatus for central Baffin Island (Wynne-Edwards, 1952), southern Somerset Island (Shortt and Peters, 1942) and the Melville Peninsula (Bray, 1943), all of which are within $350 \mathrm{~km}$ of Arctic Bay.

We first recorded this species on 18 June. Bray (1943) reported the earliest spring arrivals on 8 June. On 3 July at least 10 individuals were engaged in 
courtship flights along the river below Marcil Lake. During a return visit on 24 July, none was observed in any of the areas where the species had been seen previously. However, two adults with two young ( $~ 5$ days old) were observed on a sparsely-vegetated delta on the north shore of Marcil Lake. Both young were captured and the distinctive webbing on the toes was photographed.

\section{Cosmopolitan Species}

HORNED LARK. Eremophila alpestris. First observed on 22 May. The first evidence of breeding was noted as early as 27 May when two males were seen singing on bare talus slopes near Oulouksione Point. By 3 June the species was widespread, but was especially common on the dry south- and east-facing slopes near the village; at least 10 displaying males were observed there on this date. On 3 July a flightless juvenile was caught, and on 7 July an adult was seen feeding several fledged young. In mid-July the Horned Lark was the most conspicuous passerine in the area, outnumbering even the Snow Bunting and Lapland Longspur. Horned Larks remained numerous until late August when up to 35 were seen on a $2-\mathrm{km}$ hike between the village and Oulouksione Point. Our latest observation was of a single individual on 7 September.

COMMON RAVEN. Corvus corax. Ravens were observed regularly throughout our stay; at least two pairs nested in the area. Adults were observed carrying food from the dump to St. George's Society Cliffs on 18 and 27 May. On 14 July, five ravens, at least one of which was a newly-fledged young, were seen in the same area. On 24 June, a nest with two large young was found on a cliff ledge of the dyke between Marcil Lake and Adams Sound. During August and September flocks of up to 25 were seen at the dump at Nanisivik Mine. Residents of Arctic Bay stated that ravens occur both at the village dump and at Nanisivik Mine during the winter. Ellis (1954) observed ravens at Arctic Bay during November 1954.

\section{NOTES ON OTHER SPECIES, 1976}

NORTHERN FULMAR. Fulmarus glacialis. Fulmars did not appear at Arctic Bay until 24 July (2 individuals) when the bay was $65 \%$ ice-free. Between 27 July and our departure on 28 September up to 130 were seen daily. In 1954, Ellis (1959) noted fulmars at Arctic Bay until 19 October, the day after solid ice covered the waters of the bay. A favorite activity of Inuit children was baiting fulmars with pieces of seal fat on a rod and reel. During the course of the summer, several dozen fulmars were caught and killed in this manner.

The nearest colony (estimated to contain 25,000 pairs of fulmars) is located between Baillarge Bay and Elwin Inlet $50 \mathrm{~km}$ north of Arctic Bay (Brown et al., 1975).

COMMON EIDER. Somateria mollissima. Positively identified only once; a female with a flock of 29 female King Eiders on 15 August.

BLACK-BELLIED PLOVER. Pluvialis squatarola. Observed only once; two individuals feeding with an American Golden Plover on 18 June. 
RUDDY TURNSTONE. Arenaria interpres. Turnstones were first observed on 3 June when two were found feeding on the snow-free slopes north of the village. From one to ten were noted regularly at the dump until 9 June. Two were seen flying along the beach at Victor Bay on 22 June and one was flushed from the beach on 3 July. Their absence as a breeder both here and elsewhere on northern Baffin Island supports the assumption that there is a gap between the breeding ranges of the Old World subspecies, A.i. interpres, and the New World subspecies, A.i. morinella (Snyder, 1957; Godfrey, 1966).

RED KNOT. Calidris canutus. From three to eight, most of which were feeding with Ruddy Turnstones at the dump, were recorded from 4-9 June. As with the previous species, northern Baffin Island may be in the hiatus between the breeding ranges of the Old World population, C.c. canutus, and the New World population, C.c. rufa (Snyder, 1957; Godfrey, 1966).

RED PHALAROPE. Phalaropus fulicarius. A pair was seen on a pond near Marcil Lake on 24 June; a female was seen at the same location on 3 July.

BLACK GUILLEMOT. Cepphus grylle. One record, a single individual in breeding plumage along the west shore of the Uluksan Peninsula on 29 August. Brown et al. (1975) show the breeding range extending along the east shore of Admiralty Inlet south to Steensby Peninsula. In view of the late date of ice break-up in the area and the paucity of observations, it seems unlikely that guillemots breed except on the outermost coasts of the inlet. In 1976, aerial surveys along coasts showed that the nearest breeding locality, containing at least 60 birds, was located near Cape Joy, Borden Peninsula, 95 $\mathrm{km}$ northeast of Arctic Bay.

SNOWY OWL. Nyctea scandiaca. Although there were numerous indications (pellets) that owls had been present in the area, and residents stated that several had been seen in the area during the previous summer, we observed the species only once, on 31 May. Their low numbers may be attributable to the scarcity of lemmings near Arctic Bay in 1976. The nearest area where Snowy Owls were consistently observed in 1976, and probably nested, was on the north coast of the Borden Peninsula.

WHEATEAR. Oenanthe oenanthe. Although we spent much time searching potentially suitable habitat, this species was observed only twice. Two males were seen on 31 July, and a female or immature was seen on 23 August (G. Johnston, LGL Ltd., pers. comm.).

\section{DISCUSSION}

The known avifauna of the Arctic Bay area consists of 39 species: 22 are proven or suspected breeders (Rock Ptarmigan, Common Raven and Hoary Redpoll are permanent residents), 14 are transients, and three are accidentals (Whimbrel, Bank Swallow, Wilson's Warbler). Eleven of the breeders have trans-arctic (primarily circumpolar) ranges, five have predominantly high arctic ( 3 North American; 2 circumpolar) ranges, four have predominantly low arctic ( 2 North American; 2 circumpolar) ranges, and two are cosmopolitan. Two typical high arctic shorebirds, Red Knot and Ruddy Turnstone, do not breed in the Arctic Bay area. Many typical low arctic species are also absent 
(e.g. Arctic Loon, Sandhill Crane and Willow Ptarmigan are reported to nest north to the Steensby Peninsula, $100 \mathrm{~km}$ south of Arctic Bay - D. Ipirq, pers. comm.). Arctic Bay appears to be in a transition zone between typical low and high arctic avifaunas.

Only one of the proven breeding species, Ringed Plover, has a predominantly Eurasian breeding range; but three transients - the Wheatear and the Old World subspecies of the Red Knot and Ruddy Turnstone - also have predominantly Eurasian distributions. The local subspecies of the Hoary Redpoll (C.h. hornemanni) has a predominantly Greenlandic distribution (A.O.U. 1957).

Three species known to be transients, Red Phalarope, Snowy Owl and Wheatear, may breed in the Arctic Bay area during some years. There are apparently no breeding records for 12 other species that other sources indicate may breed at or near Arctic Bay (Snyder, 1957; Godfrey, 1966; Brown et al., 1975). The absence of breeding Arctic Loons, Northern Fulmars, Black-legged Kittiwakes, Thick-billed Murres, Black Guillemots and possibly Arctic Terns, may be related to the normally late date of ice break-up in Admiralty Inlet. More systematic coverage of the Arctic Bay area may reveal irregular occurrences and/or low densities of the Parasitic Jaeger (in lemming years), Black-bellied Plover, Purple Sandpiper and Sanderling. The Brant and the Common Eider reportedly nest in south and west Admiralty Inlet, respectively, but are absent as breeders at Arctic Bay (D. Ipirq, pers. comm.).

\section{ACKNOWLEDGEMENTS}

D. Ipirq of Arctic Bay, W. Doidge and R. Greendale of Canada Fisheries and Marine Services and K. J. Finley and G. J. Johnston of LGL Ltd. made several observations included in this report. Our stay in Arctic Bay was made possible through Dr. A. Rutgers, Norlands Petroleums Ltd. We thank W. J. Richardson, M. S. W. Bradstreet, R. A. Davis, L. A. Patterson, R. A. Salter and C. E. Tull for constructive criticism of the manuscript.

\section{REFERENCES}

A.O.U. 1957. Check-list of North American birds. Fifth ed. American Ornithologists' Union, Baltimore, Maryland.

BRAY, R. 1943. Notes on the birds of Southampton Island, Baffin Island and Melville Peninsula, (with comments by T. H. Manning). Auk $60: 504-536$.

BROWN, R. G. B., NETTLEShIP, D. N., GERMAIN, P., TULL, C. E. and DAVIS, T. 1975. Atlas of easterm Canadian seabirds. Canadian Wildlife Service, Ottawa.

DRURY, W. H., Jr. 1960. Breeding activities of Long-tailed Jaeger, Herring Gull and Arctic Tern on Bylot Island, Northwest Territories, Canada. Bird-Banding 31: 63-78.

DRURY. W. H.. Jr. 1961a. Studies of the breeding biology of Horned Lark, Water Pipit, Lapland Longspur and Snow Bunting on Bylot Island, Northwest Territories, Canada. Bird-Banding 32: $1-46$.

DRURY, W. H. J J. 1961b. The breeding biology of shorebirds on Bylot Island, Northwest Territories, Canada. Auk 78: 176-219.

DRURY, W. H., Ji. 1961c. Observations on some breeding water birds on Bylot Island. Canadian Field-Naturalist 75: 84-101. 
ELLIS, D. V. 1956. Observations on the migration, distribution and breeding of birds in the Canadian Arctic during 1954 and 1955. Dansk Ornithologisk Forenings Tidesskrift 50: 207-230.

GEALE. J. 1971. Birds of Resolute, Comwallis Island, N.W.T. Canadian Field-Naturalist 85: 53-59. GODFREY, W.E. 1966. The Birds of Canada. National Museum of Canada, Bulletin 203, Ottawa.

HUSSELL, D. J. T. and HOLROYD, G. L. 1974. Birds of the Truelove Lowland and adjacent areas of northeastem Devon Island, N.W.T. Canadian Field-Naturalist 88: 197-212.

MacDONALD, S. D. and MacPHERSON, A. H. 1962. Breeding places of the Ivory Gull in Arctic Canada. National Museum of Canada, Bulletin 183: 111-117.

MALTBY. L. S. 1978. Birds of the coastal zone of Melville Island, 1973-1975. Canadian Field-Naturalist 92: 24-29.

PARMELEE, D. F., STEPHENS, H. A. and SCHMIDT. R. H. 1967. The birds of southeastern Victoria Island and adjacent small islands. National Museum of Canada, Bulletin 222, Ottawa.

PATTIE. D. L. 1977. Population levels and bioenergetics of arctic birds on Truelove Lowland. pp. 413-436. In: L. C. Bliss (ed.). Truelove Lowland, Devon Island, Canada: a high arctic ecosystem. University of Alberta Press, Edmonton, Alberta.

POLUNIN, N. 1948. Botany of the Eastern Canadian Arctic. Part III: vegetation and ecology. National Museum of Canada Bulletin 104, Ottawa.

SHORTT, T. M. and PETERS, H. S. 1942. Some recent bird records from Canada's Eastern Arctic. Canadian Journal of Research 20: 338-348.

SMITH, N. G. 1966. Evolution of some arctic gulls (Larus): an experimental study of isolating mechanisms. Ornithological Monographs 4, American Ornithologists' Union.

SNYDER, J. D. 1957. Arctic birds of Canada. University of Toronto Press, Toronto.

SOPER, J. D. 1928. A faunal investigation of southern Baffin Island. National Museum of Canada, Bulletin 53: 76-116.

TUCK. L. M. and LEMIEUX, L. 1959. The avifauna of Bylot Island. Dansk Ornithologisk Forenings Tidesskrift 53: 137-154.

VAN TYNE, J. and DRURY, W. H. 1959. The birds of southern Bylot Island, 1954. Occasional papers of the Museum of Zoology, University of Michigan, Number 615: 1-37.

WYNNE-EDWARDS, v. C. 1952. Zoology of the Baird Expedition (1950). I. The birds observed in central and southeast Baffin Island. Auk 69: 353-391. 